\title{
The Urgency of Edutainment in Islamic Education Learning
}

\author{
Imam Mudjiono \\ Islamic Education Department \\ Islamic University of Indonesia \\ Yogyakarta, Indonesia \\ imam.mudjiono@uii.ac.id
}

\begin{abstract}
This paper aims to describe the importance of entertainment in learning process within Islamic education framework. It uses a library research to analyses some critical issue in learning and suggest the use of more entertainment content in learning process. The results of the study can be implemented in the context of Islamic education in Indonesia.
\end{abstract}

\section{Keywords: Islamic Education, Learning Style, Edutainment}

\section{INTRODUCTION}

Common problem that often occur in the learning process at school include: First, in carrying out their duties, the majority of the education still act as sub-branches and feel they are the only source of information and knowledge. While the students are considered as object which must be filled. In learning like this there is no interaction in the form of dialogue, discussion, or exchange of opinions. [4]

Second, educators generally still make the lecture method the dominant method. Case studies of Sahyar and Afrianti (2010), who took samples at one of the junior high schools in the city of Medan. Results of the study revealed that the factors that cause poor performance or achievements of learners are: absorption of subject matter a low absorption capacity in understanding the study materials given too low, and learners are less active during learning activities that take place in the classroom. It was also stated that students rarely repeat or relearn subject matter that has been delivered by the educator, as well as less the concentration of participants in learning. In addition, the learning methods applied by educators are conventional methods, such as lecture and question and answer methods. [5]

Third, a number of studies on learning illustrate more about the number of students who come to school feeling depressed by school administrators (including educators), because the learning patterns tend to still use a bureaucratic approach, not a pedagogical approach. [6] As a consequence, students are not optimal in learning, because of the unpleasant atmosphere.

Fourth, the educators that administer the subjects of Islamic Religious Education (PAI) especially, in general often do not care about what is required of students during the learning. Since most Indonesians are still optimistic about the role of schools in teaching religious education to their children, it is very important to always actualize the material and learning methods and steps to empower educators to be more able to become creative and innovative figures. Their existence as a facilitator of improving the ability of students to express their faith and trust to answer the challenges of life of students. [7]
Such an old paradigm is a learning pattern that places educators as subjects and students as objects and bureaucratic approaches, it cannot be maintained anymore. However, it must be admitted that such activities are still ongoing in some educational institutions. [8]

Learning that takes place with a forceful approach, both physically and non-physically, will only create a nonconducive learning atmosphere. In addition to students feeling uncomfortable, it also contains potential that brings fear, even students can experience stress.

This condition is very difficult to achieve optimal learning processes and outcomes. The learning process requires a comfortable and pleasant atmosphere. Learning never works optimally in the real sense, if done in an atmosphere that is forced, threatening and frightening. [9]

As also said Darmansyah, that the learning process that takes place in an atmosphere that is not conducive, can bring up various actions and behaviors of students who do not support the creation of effective, even counter-productive learning processes. The reaction of students who can be witnessed directly is a picture of boredom, sleepiness, talking to a friend next door, playing a cellphone, going out in class, playing truant, or disturbing other friends. [10]

Other indications of students' dislike of certain teaching methods, can be detected from the symptoms that arise such as: a happy attitude if the educator is accidentally unable to attend. Especially if those who are unable to attend are educators whose teaching methods are not in accordance with the principles that can create a sense of pleasure and comfort among students. The problem of students' displeasure with the learning process can indeed be caused by various interrelated factors. However, it must be acknowledged that most of it is caused by the inability of educators to create a happy or pleasant atmosphere as the most dominant factor.

Therefore educators should always try to improve the quality of the model and the application of appropriate learning methods, so that students can enjoy enjoyable learning. [11]

Theoretically, increasing motivation and learning achievement of students is inseparable from the role of educators as parties who teach and guide students. This illustrates that learning is a process of interaction between educators and students based on educational relationships in the context of achieving learning goals. [12]

The role of educators as managers in classroom learning activities has long been recognized as one of the important 
factors in improving student achievement. As professionals, educators are required not only to be able to manage learning but also to be able to manage classes, namely to create and maintain optimal learning conditions for achieving teaching goals. [13]

\section{RESULTS}

The learning process in the classroom should be exciting and take place in a happy atmosphere, so that the entrance for new information will be wider and can be recorded properly. If students do activities with pleasure, not forced, learn spontaneously, without burden, the results will be more optimal and according to the target to be achieved. This can occur because of the unification of feelings in the activities of play, learning and work, which are inseparable between educators and students. If this kind of mood can grow in the education process, the results will be very positive and the learning environment will be more fun, because the class atmosphere looks more competitive, active and joyful. [14]

Learning is not just the delivery of information into the minds of students and this activity also requires the mental involvement and actions of students. Explanation and demonstration have not yet led to real learning if they have not taken the active learning model. Active learning is the right step to create a pleasant and interesting atmosphere for students. Through such a learning model, students can move to move around, communicate, discuss, interact and think hard, so as to avoid a saturated and boring atmosphere. [15]

As Eric Jensen said that Gordon Dryden quoted, states that the three main elements that influence the learning process are circumstances, strategy and content. Circumstances, related to the creation of a conducive atmosphere or excited to learn. Learning strategies relate to teaching styles or learning methods. While content is subject matter taught by educators. [16]

In a view that is almost the same as Eric Jensen, Prashnig (1998), also mentions that aspects that are often a source of problems in the world of education, are not a problem of "what" is taught, but rather "how" to teach subject matter. Students who come to school with full energy, passionate enthusiasm, great curiosity, often look tired, upset, bored, not eager to learn when attending class, not because of the material but more due to teaching methods. [17]

Thus it can be explained that an effective learning model is a learning process that is able to deliver students to be in a happy state. Joy in learning is thought to be able to have a tremendous effect on the achievement of learning outcomes. [18] Ideally, every learning activity must take place in a pleasant atmosphere, so that all processes of transfer of knowledge, values and skills can take place effectively.

As explained, the pleasant learning atmosphere is more influenced by educator factors and is very much based on the chosen learning strategy. Learning strategies that can please students are active learning strategies, because they tend to make the learning environment more fluid and students play more roles with student centered. Pleasant educators are educators who show friendship attitudes and behaviors, both during learning and in relationships outside the learning time. That is, educators have a sympathetic appearance at all times, so they can make the learning process effective and efficient. [19]
A learning process can be said to be fun, if during learning all students focus their attention fully on the ongoing learning activities. According to the results of several studies, the high time of attention proved to be able to improve learning outcomes.

The pattern of active and fun learning must indeed be equipped with an effective learning model, in order to produce what should be mastered by students after the learning process takes place, according to the objectives that must be achieved. If a learning process does not result in the achievement of learning goals, it is not like playing. [20]

\section{CONCLUSION}

Achievement of learning outcomes, apart from being determined by the learning model, can also be influenced by the level of participation of students. If students are active and participate in the learning process, what is achieved is not only the achievement aspect, but also extends to the affective and social aspects.

Given the importance of aspects of student participation in the learning process, educators must be able to create learning situations that involve more participation of students by increasing aspects of student participation in learning, so that students' achievement will also increase. [21]

\section{REFERENCES}

[1] Undang-Undang SISDIKNAS, UU RI No. 20 / 2003, (Jakarta: Sinar Grafika, 2003), p. 73.

[2] Arifin, Penelitian Pendidikan Pendekatan Kuantitatif dan Kualitatif,, (Yogyakarta: Lilin Persada, 2010), p. 244.

[3] Hamruni, Konsep Edutainment dalam Pendidikan Islam (Yogyakarta: Academic Field UIN Yogyakarta, 2008), p. 3.

[4] Jamal Ma'mur Asmani, 7 Tips Aplikasi PAKEM, Pembelajaran Aktif, Kreatif, Efektif, dan Menyenangkan, (Yogyakarta, DIVA Press, 2011), p. 6 .

[5] Sahyar and Eka Afrianti, Perbedaan Hasil Belajar Siswa dengan Menggunakan Metode Mind Mapping dan Metode yang Konvensional pada Materi Pokok Zat dan Wujudnya di Kelas VII Semester 1 SMPN 28 Medan, (Penelitian PTK Jurusan Fisika, FMIPA Universitas Negeri Medan, 2010).

[6] Assegaf, Abdurahman Nonviolent Education: Typology of Conditions, Cases and Concepts, Yogyakarta: Tiara Wacana, 2004) p. 7-22.

[7] Ministry of Religion, Summary of Reports, Research on Problems in Religion Education, Research in Elementary, Middle School, High School in Jogjakarta City 2004-2006.

[8] Anita Lie, Cooperative Learning, (Jakarta: Grasindo, 2004), p. 3.

[9] Hamruni, Edutaiment Dalam Pendidikan Islam dan Teori-teori Pembelajaran Quantum (Yogyakarta: Fakultas Tarbiyah Universitas Islam Negeri (UIN) Sunan Kalijaga, 2009), hlm. vi-vii.

[10] Darmansyah, Strategi Pembelajaran Menyenangkan dengan Humor, (Jakarta: Bumi Aksara, 2010), p. 6.

[11] Winarno Surachmad, Pengantar Penelitian Ilmiah, (Bandung: Tarsito, 1994), p. 52.

[12] Wiwik Ida Kurotul Aini, Classroom Management Strategy in Improving Student Learning Achievement in Public High Schools (Case Study at SMAN 1 Kepanjen Malang), (Malang: 2009), p. 17

[13] Komaruddin Hidayat, "Introduction" in Melvin L Silberman, Active Learning 101 Learning Strategies, occur. Sarjuli, (Yogyakarta: Insan Mandiri, 2007), p. xvi.

[14] Melvin L Silberman, Ibid . p. xxi.

[15] Gordon Dryden \& Jeannette Vos, The Learning Revolution: To Change the Way the World Learns, New Zealand: The Learning Web, 1999), p. 307.

[16] Barbara Prashnig, The Power of Diversity of New Ways of Learning and Teachings through Learning Styl e, (Stanfford: Network Educational Press Ltd., 1998), p. 203. 
[17] Darmansyah, Learning Strategy p. 3.

[18] Sukadi, Guru Malas dan Guru Rajin: Ramuan Ajaib Untuk Menjadi guru Menenangkan, (Bandung: MQS, 2010) p.59.
[19] Hamzah B. Uno, Belajar Dengan Pendekatan PAILKEM Approach, (Jakarta, Bumi Aksara, 2011), p.210.

[20] Taniredja Tukiran, "Research for Teacher Professional Development ", (Bandung: Alfabeta, 2010) p.89-90. 